\title{
Mycotoxin Contamination Concerns of Herbs and Medicinal Plants
}

\author{
Iwona Ałtyn ${ }^{(1)}$ and Magdalena Twarużek * $\mathbb{D}$ \\ Department of Physiology and Toxicology, Faculty of Biological Sciences, Kazimierz Wielki University, \\ Chodkiewicza 30, 85-064 Bydgoszcz, Poland; iwonaalt@ukw.edu.pl \\ * Correspondence: twarmag@ukw.edu.pl
}

Received: 21 January 2020; Accepted: 12 March 2020; Published: 14 March 2020

\begin{abstract}
Plants and medicinal herbs that are available on the market do not always meet quality and safety standards. One particular concern is the risk of contamination with mycotoxins. Aflatoxins and ochratoxin A are the most frequently described mycotoxins in herbal products and have repeatedly been reported to occur at concentrations which exceed regulatory levels set by the European Union (EU). Possible solutions include enforcing existing limits, and for the new materials, establishing tighter limits and mandate the growth of medicinal plants in EU member countries under more strict conditions.
\end{abstract}

Keywords: herbs; contamination; liquorice; chamomile; mint; ginseng; milk thistle; ginger; medicinal plants; mycotoxins

Key Contribution: The aim of the present review is to determine the mycotoxicological status of herbal products and to highlight some important challenges associated with effective monitoring of their safe usage.

\section{Introduction}

Humans have used extracts derived from medicinal plants in folk medicine systems for thousands of years $[1,2]$ and these traditions continue to the present day. According to the World Health Organization (WHO), "a medicinal plant is defined as any plant which, in one or more of its organs, contains substances that can be used for therapeutic purposes, or which are precursors for chemo-pharmaceutical semi-synthesis" [3]. Many licensed drugs were originally derived wholly or partially from extracts of medicinal plants that had long histories of folk usage [4].

In 1995, the global market for medicinal herbs was approximately USD 17 billion, but a recent market analysis suggests that by 2023 this will increase to approximately USD 111 billion (compound annual growth rate of $7 \%$ to $8 \%$ ). Market drivers for this increased demand in developed countries include the expense of insurance-based medical care, a rising desire of people in industrialized nations to take charge of their own health, and an increasing elderly population [5].

Some well-known systems of using herbal medicine are Ayurveda from India and Traditional Chinese Medicine (TCM), although the latter includes a variety of products of animal and fungal origin. Therefore, herbal products are beyond the scope of this review and are not systematically covered herein. The use of herbal or folk medicine has always been widespread in less developed countries, mainly because of a lack of modern healthcare. Often it is the primary, if not the only, means of treating the sick in $80 \%$ of Asian and African countries [6,7]. In developed countries, herbal medicines are also consumed. The United States Food and Drug Administration (US-FDA) estimated a decade ago that more than 20,000 different plant species were used in herbal remedies each year, and that one out of 
five US citizens used herbal medicines regularly [4]. In the European Union (EU), France, and Germany are the main markets for herbal remedies [5].

One of the most serious issues surrounding the safety of medicinal herbs concerns regulating the level of mycotoxins found in herbal preparations. Mycotoxins are a group of around 400 toxic secondary metabolites produced by fungi such as Aspergillus, Penicillium, Fusarium, Claviceps, and Alternaria. A detailed treatment of the effects of these fungal toxins is beyond the scope of this review; for an exhaustive survey see Selwet [8] and Zain [9]. Mycotoxins have previously been defined as "fungal metabolites that when ingested, inhaled or absorbed through the skin, cause illness or human and animal death" [10-12]. Collectively mycotoxins can cause carcinogenic and other manifold toxic effects $[13,14]$.

The mycotoxins most damaging to the health of humans and domestic animals are aflatoxins (AF), ochratoxin A (OTA), fumonisins (FB), zearalenone (ZEN), and deoxynivalenol (DON) [15-18]. The toxic properties, their occurrence, and their relevance in foods and feeds have been the subject of numerous comprehensive reviews, including the JECFA (Joint FAO/WHO Expert Committee on Food Additives), IARC (International Agency for Research on Cancer), EFSA (European Food Safety Authority), and other agencies [15-21]. Issues of analysis with regard to mycotoxins in herbal medicines have been reviewed recently by Zhang et al. [22].

\section{Regulations Concerning Production and Distribution of Medicinal Herbs}

Medical pharmacopeias, such as the European Pharmacopeia, are part of the strict legal frameworks used to regulate licensed drugs. Any compound included in a pharmacopeia is subject to very stringent pre- and post-market checks before it can be offered for sale. The product should meet the quality standards in the respective pharmacopoeias of the Member State or the European Pharmacopoeia. Bibliographic evidence should confirm the existence of a product in medicine for at least 30 years, including at least 15 years in the European community. [23]. Most herbal products are treated as "food supplement", "herbal supplement", or "traditional medicine" as part of a "fast track" regulatory system, whereby plants that are deemed (a) non-toxic and (b) have a written tradition of medicinal use are subject to less scrutiny. This approach is used particularly in the US, EU, Canada, and Australia [24,25].

International trade of herbal plants is subject to compliance with international treaties including the "Convention on International Trade of Endangered Species of Wild Fauna and Flora" (CITES). The CITES treaties deal with the control of international trade in certain species that are threatened with extinction. Herbal products are subject to various classifications, including complimentary medicines, natural health products, prescription medicines, over the counter medicines, supplements, traditional herbal medicines, etc. [26]. While drugs are tightly regulated, the scope of control over supplements is relatively low. In order to harmonze the classification of traditional preparations in countries where there is no established system of regulation in the field of traditional medicine, the WHO published a series of Traditional WHO Medicine Strategy papers for 2002 to 2005 and for 2014 to 2023. The strategy for 2002 to 2005 includes shaping government policy; ensuring safety, efficiency and quality; improving access; and promoting the proper use of traditional and complementary medicines [27]. The current strategy for 2014 to 2023 has two key objectives, first, to support member states in using the potential contribution of traditional and complementary medicines in health, well-being, and healthcare focused on people, and second, promoting safe and effective use of these medicines through regulation of products, practices, and practitioners [28].

The Scientific Panel for the European Food Standards Agency (EFSA) developed a document which provided an evidence-based framework against which the safety of botanical preparations could be judged [19]. This framework was based on the earlier recommendations of Schilter et al. [29]. Then, the EFSA further developed a two-level tiered system for the licensing of botanical preparations [30]. The European Medicine Agency (EMA) has laid down different methods of registering herbal medicinal products. The first is a full marketing authorization by submission of a dossier, which provides the 
information under directive 2001/83/EC. The second method is used for traditional herbal medicinal products, whereby a simplified procedure under regulation 2004/24/EC is followed [31,32].

The United States Food and Drug Administration has classified botanical products as drug, food or a dietary supplement on the basis of claims or end uses thereof. As per the FDA, a drug must be marketed under an approved New Drug Application (NDA), while dietary supplements are regulated under the Dietary Supplement Health and Education Act of 1994 [23]. Table 1 shows a compilation of the European Union, US-FDA, and European Pharmacopeia regulations with regard to mycotoxins in various foodstuffs.

Table 1. Regulations for mycotoxins in food.

\begin{tabular}{|c|c|c|c|c|}
\hline Mycotoxins & Food Category & $\begin{array}{c}\text { European Union, } \\
\text { Regulation 1881/2006 } \\
{[\mu \mathrm{g} / \mathrm{kg}]} \\
{[33-35]}\end{array}$ & $\begin{array}{c}\text { USA, FDA action } \\
\text { level } \\
{[\mu \mathrm{g} / \mathrm{kg}]}\end{array}$ & $\begin{array}{c}\text { European } \\
\text { Pharmacopeia 2.8.18. } \\
{[\mu \mathrm{g} / \mathrm{kg}]} \\
{[36]}\end{array}$ \\
\hline \multirow{5}{*}{$\begin{array}{l}\text { Aflatoxin } B_{1} \\
\left(\text { Sum of } B_{1}, B_{2}\right. \\
\left.G_{1} \text { and } G_{2}\right)\end{array}$} & Herbal drugs & - & - & $\begin{array}{l}<2 \\
(4)\end{array}$ \\
\hline & Ginger & $\begin{array}{c}5 \\
(10)\end{array}$ & - & - \\
\hline & Dried figs & $\begin{array}{c}6 \\
(10)\end{array}$ & - & - \\
\hline & Cereal-based foodstuffs & $\begin{array}{c}2 \\
(4)\end{array}$ & 20 & - \\
\hline & $\begin{array}{l}\text { Processed cereal-based foods } \\
\text { and baby foods for infants and } \\
\text { young children }\end{array}$ & 0,10 & - & - \\
\hline Deoxynivalenol & Cereal-based foodstuffs & $200-750$ & 1000 & - \\
\hline \multirow{5}{*}{ Ochratoxin A } & $\begin{array}{l}\text { Liquorice root, ingredient for } \\
\text { herbal infusion }\end{array}$ & 20 & - & 20 \\
\hline & Liquorice extracts for use in food & 80 & & 80 \\
\hline & Ginger & 15 & - & - \\
\hline & Cereal-based foodstuffs & $3-5$ & - & - \\
\hline & $\begin{array}{l}\text { Processed cereal-based foods } \\
\text { and baby foods for infants and } \\
\text { young children }\end{array}$ & 0,5 & - & \\
\hline Patulin & Foodstuffs & $10-50$ & 50 & - \\
\hline Zearalenone & Cereal-based foodstuffs & $20-100$ & - & - \\
\hline
\end{tabular}

Other countries have set similar regulations, although the maximum tolerated levels can vary. For example, the maximum limit for aflatoxin in India appears to be much higher $(30 \mu \mathrm{g} / \mathrm{kg})$ than in other countries [37,38]. In China, 5 to $20 \mu \mathrm{g} / \mathrm{kg}$ is the maximum limit depending upon the classification of the medicinal herb under consideration [33,36,39]. Mycotoxin contamination is particularly serious in India as many of the companies with the largest worldwide market share of medicinal herb sales are located there [15]. Indeed, there have been so many instances of problems with food imports from India containing high levels of mycotoxins that current EU regulations require $50 \%$ of all shipments of Capsicum (chili powders and peppers), Zingiber officinale (ginger), and Curcuma longa (turmeric) be tested for mycotoxins (EC 669/2009).

\section{Data on Contamination of Selected Medicinal Plants by Mycotoxins}

Mycotoxin contamination of selected medicinal plants belonging to the European Pharmacopoeia are now discussed, specifically for liquorice, chamomile, mint, ginseng, milk thistle, and ginger [36].

\subsection{Glycyrrhiza Glabra (Liquorice)}

Liquorice is a sweet extract from the root of Glycyrrhiza glabra L. which is frequently used in confectioneries. The main flavoring ingredient, glycyrrhizin, has various pharmaceutical properties. 
For example, it acts as an expectorant, has anti-inflammatory properties, and increases blood pressure. Excessive consumption of liquorice can also have adverse health effects. Despite the known health risks, liquorice is part of both TCM and Ayurveda [39]. Although liquorice itself is not susceptible to pests, the root can be infected by toxigenic fungi postharvest. This can be worsened by damages caused by aphid infestations, to which the plant seems to be quite susceptible. Several studies report relatively high levels of AFs and OTA in liquorice roots and in commercial liquorice products such as confectionary items. Specifically, the levels of OTA exceeded $100 \mu \mathrm{g} / \mathrm{kg}$ in some highly contaminated root samples, and thereby also exceeded the European Union maximum level in these products. In finished products, levels were lower but still at a notable level. In this context, it is important to consider that liquorice is frequently used as a sweetener in tea beverages for infants of less than one year of age [40]. The overall frequency and levels of AFs were considerably lower, and reports on the occurrence of other mycotoxins are largely anecdotal. The data obtained for mycotoxins in liquorice roots were mostly reported for food products, and analyses of liquorice products as herbal medicines are scarce. Tan et al. [41] in a survey of 138 TCMs from the Chinese market for Fusarium toxins T-2 and HT-2 found that only one sample of barley malt (Hordeum vulgare) was positive for T-2, while all three samples of liquorice were negative (Table 2). However, other research conducted for fumonisins showed their lack in products [42,43] or in the case of Roy et al.'s work [44], a low level.

Table 2. Analysis of the literature available on mycotoxin contamination in liquorice and liquorice products.

\begin{tabular}{|c|c|c|c|c|c|c|}
\hline Mycotoxins & Sample Type & $\begin{array}{c}\text { Number of } \\
\text { Samples }\end{array}$ & $\begin{array}{l}\text { Percentage } \\
\text { of Positive } \\
\text { Results (\%) }\end{array}$ & $\begin{array}{c}\text { Range of } \\
\text { Positive Results } \\
(\mu \mathrm{g} / \mathrm{kg})\end{array}$ & $\begin{array}{l}\text { Percentage of } \\
\text { "Critical"* } \\
\text { Positive } \\
\text { Samples (\%) }\end{array}$ & Reference \\
\hline $\mathrm{AF}$ & Liquorice root & 1 & 100 & 0.59 & 0 & [45] \\
\hline \multirow{2}{*}{ OTA } & Liquorice root & 19 & 47 & n.d. -216.5 & 22 & \multirow{2}{*}[40]{} \\
\hline & Liquorice sweet & 19 & 95 & n.d.-3.0 & 0 & \\
\hline $\mathrm{AF}$ & \multirow{2}{*}{ Liquorice root } & 10 & 40 & n.d. -0.17 & 0 & \multirow{2}{*}{ [44] } \\
\hline OTA & & 10 & 20 & n.d. -0.05 & 0 & \\
\hline FB & Liquorice & 1 & 0 & n.d. & - & {$[43]$} \\
\hline \multirow{5}{*}{ OTA } & Dried liquorice roots & 15 & 100 & $1.4-252.8$ & 7 & \multirow{5}{*}{ [46] } \\
\hline & Fresh liquorice root & 8 & 100 & $3.3-14.7$ & 0 & \\
\hline & Liquorice sweets & 4 & 100 & $0.5-8.2$ & 0 & \\
\hline & Liquid liquorice & 2 & 100 & $14.6-17.3$ & 0 & \\
\hline & Liquorice block & 1 & 100 & 39.5 & 100 & \\
\hline $\mathrm{FB}$ & Liquorice & 1 & 100 & 647 & 100 & [21] \\
\hline & \multirow{4}{*}{$\begin{array}{l}\text { Dried Liquorice } \\
\text { Liquorice } \\
\text { confectionery }\end{array}$} & \multirow{4}{*}{$\begin{array}{l}28 \\
54\end{array}$} & 100 & 26.3-990.1 & 100 & \multirow{4}{*}{ [47] } \\
\hline ОТА & & & 61 & $<$ LOD-8.3 & 0 & \\
\hline \multirow{2}{*}{$\mathrm{AF}$} & & & 18 & $<$ LOD-2.4 & 20 & \\
\hline & & & 15 & $<\mathrm{LOD}-7.7$ & 12,5 & \\
\hline OTA & Liquorice & 1 & 100 & 0,2 & 0 & [48] \\
\hline T-2, HT-2 & $\begin{array}{c}138 \text { TCM samples } \\
\text { including } 3 \text { samples } \\
\text { of liquorice roots }\end{array}$ & 3 & 0 & n.d. & - & [49] \\
\hline $\mathrm{AF}$ & \multirow{2}{*}{ Liquorice root } & \multirow{2}{*}{21} & 14 & $<$ LOQ-26.11 & 33 & \multirow{2}{*}[50]{} \\
\hline OTA & & & 5 & $<$ LOQ-18.73 & 0 & \\
\hline $\mathrm{AF}$ & \multirow{2}{*}{ Liquorice root } & \multirow{2}{*}{4} & 50 & n.d.-9.34 & \multirow{2}{*}{0} & \multirow{2}{*}{ [51] } \\
\hline OTA & & & 75 & n.d.-13.1 & & \\
\hline \multirow{5}{*}{$\begin{array}{l}\text { CIT DON } \\
\text { FB }_{1} \\
\text { OTA ZEN }\end{array}$} & & & 6 & $6.75-20.44$ & 50 & \multirow{5}{*}{ [42] } \\
\hline & & & 3 & $<$ LOQ-11.08 & 0 & \\
\hline & Liquorice & 31 & 6 & $<$ LOQ-39.34 & 0 & \\
\hline & & & 3 & $<\mathrm{LOQ}-3.93$ & 0 & \\
\hline & & & 13 & $3.37-8.75$ & 0 & \\
\hline
\end{tabular}

* Critical-under the UE regulations limits of mycotoxins; AF-Aflatoxin, OTA-Ochratoxin A, FB-Fumonisin, ZEN-Zearalenone, DON-Deoxynivalenol, CIT-Citrinin. 


\subsection{Matricaria Chamomilla (Chamomile)}

Matricaria chamomilla L. is the most popular source of the herbal product chamomile, although other species are also used as "chamomile". The raw material is used internally in the treatment of gastrointestinal symptoms such as spastic stomach cramps, flatulence, belching, and inflammation of the bile duct. Externally, it is recommended to reduce local inflammation of the skin and mucous membranes, through rinsing the mouth and throat, inhalation during irritation of the upper respiratory tract, baths, rinses, and ointments for inflammation around the anus and genital organs [52]. Harvesting is carried out between the second week of March and the third week of April, when weather conditions create a favorable environment for the development of pathogens. The dried chamomile is exposed to microbiological deterioration by fungal factors in a very short time. Thus, in the first stage, molds of the most xerophilic species, Aspergillus and Penicillium, are formed. By releasing increasing amounts of moisture, these molds provide favorable conditions for more demanding organisms such as Fusarium and Rhizopus. This increases the chances that the stored product is contaminated with mycotoxins that pose a health risk [52]. Tosun and Arslan [49] analyzed chamomile for the incidence of AF and FBs and reported relatively high levels of AFs in 9 of 10 samples, with a range of 3.4 to $38.9 \mu \mathrm{g} / \mathrm{kg}$. Santos et al. [21] found the highest concentrations of AF in the all samples (35.8 to $161.0 \mu \mathrm{g} / \mathrm{kg}$ ) in two samples of flower chamomile. Other reports showed that the dried raw chamomile products were on the lower level of mycotoxin contamination (Table 3).

Table 3. Analysis of the literature available on mycotoxin contamination in chamomile.

\begin{tabular}{|c|c|c|c|c|c|c|}
\hline Mycotoxins & Sample Type & $\begin{array}{c}\text { Number of } \\
\text { Samples }\end{array}$ & $\begin{array}{l}\text { Percentage } \\
\text { of Positive } \\
\text { Results (\%) }\end{array}$ & $\begin{array}{c}\text { Range of } \\
\text { Positive Results } \\
(\mu \mathrm{g} / \mathrm{kg})\end{array}$ & $\begin{array}{l}\text { Percentage of } \\
\text { "Critical"* } \\
\text { Positive } \\
\text { Samples (\%) }\end{array}$ & Reference \\
\hline FB & Chamomile & 18 & 45 & $20-70$ & 0 & {$[53]$} \\
\hline FB & Chamomile & 1 & 0 & - & 0 & [43] \\
\hline $\begin{array}{c}\text { OTA, } \\
\text { FBs, } \\
\text { AF, } \\
\text { ZEN, } \\
\text { T-2, } \\
\text { DON, } \\
\text { CIT }\end{array}$ & Chamomile flower & 2 & $\begin{array}{c}100 \\
50 \\
100 \\
100 \\
100 \\
100 \\
100\end{array}$ & $\begin{array}{c}0.8-1.0 \\
<\mathrm{LOD}-90.0 \\
35.8-161.0 \\
7.3-12.5 \\
3.5-8.3 \\
123.4-191.5 \\
31.7-49.3\end{array}$ & $\begin{array}{c}0 \\
0 \\
100 \\
0 \\
0 \\
0 \\
100\end{array}$ & {$[21]$} \\
\hline $\begin{array}{l}\mathrm{AF} \\
\mathrm{FB}\end{array}$ & Chamomile & 10 & $\begin{array}{c}100 \\
0\end{array}$ & $\begin{array}{c}3.4-38.9 \\
-\end{array}$ & $\begin{array}{c}90 \\
-\end{array}$ & [49] \\
\hline
\end{tabular}

* Critical-under the UE regulations limits of mycotoxins; AF-Aflatoxin, OTA-Ochratoxin A, FB-Fumonisin, ZEN-Zearalenone, DON-Deoxynivalenol, CIT-Citrinin.

\subsection{Mentha sp. (Mint)}

Mentha $s p$. is a genus of plants from the family Lamiaceae. Mint is a group of perennial aromatic plants that grow widely across Europe, Africa, Australia, and North America. For centuries, mint has been used as medicinal plant for gastrointestinal and respiratory ailments, bad breath, and dandruff and as a carminative, antispasmodic, diuretic, and sedative agent [54]. It grows in various habitats, most often wet, but also on dry steppes. They are grown mainly for the smell and taste of the leaves. For example, leaves of peppermint (Mentha piperita, ) are used to obtain menthol oil which is used in the perfumery, pharmaceutical, and food industries (including the manufacture of sweets and cakes), and tobacco. Leaves of green mint (Mentha spicata) are used directly as a spice and also as a flavorant in chewing gum and toothpastes [55]. Research on mycotoxins in final mint products, mainly in the food industry, showed a low level of mycotoxicological contamination. However, Tosun and Arslan [49] showed that in two samples out of five tested, the level of AF exceeded the European Union acceptable norm (Table 4). 
Table 4. Analysis of the literature available on mycotoxin contamination in mint.

\begin{tabular}{|c|c|c|c|c|c|c|}
\hline Mycotoxins & $\begin{array}{l}\text { Sample } \\
\text { Type }\end{array}$ & $\begin{array}{l}\text { Number of } \\
\text { Samples }\end{array}$ & $\begin{array}{l}\text { Percentage } \\
\text { of Positive } \\
\text { Results (\%) }\end{array}$ & $\begin{array}{c}\text { Range of } \\
\text { Positive Results } \\
(\mu \mathrm{g} / \mathrm{kg})\end{array}$ & $\begin{array}{l}\text { Percentage of } \\
\text { "Critical"* } \\
\text { Positive } \\
\text { Samples (\%) }\end{array}$ & Reference \\
\hline $\mathrm{AF}$ & \multirow{3}{*}{ Mint } & \multirow{3}{*}{2} & 0 & - & - & \multirow{3}{*}{ [56] } \\
\hline OTA & & & 0 & - & - & \\
\hline ZEN & & & 0 & - & - & \\
\hline FB & \multirow{2}{*}{ Mint } & \multirow{2}{*}{1} & 0 & - & - & \multirow{2}{*}{ [57] } \\
\hline OTA & & & 0 & - & - & \\
\hline $\mathrm{AF}$ & Mint & 5 & 0 & - & - & [58] \\
\hline $\mathrm{AF}$ & Mint & 6 & 0 & - & - & [59] \\
\hline $\mathrm{AF}$ & Mint & 10 & 0 & - & - & [60] \\
\hline OTA, & \multirow{7}{*}{ Mint } & \multirow{7}{*}{2} & 100 & $1-1.4$ & 0 & \multirow{7}{*}{ [21] } \\
\hline FBs, & & & 0 & $<\mathrm{LOD}$ & 0 & \\
\hline $\mathrm{AF}$ & & & 100 & $16.6-29.7$ & 100 & \\
\hline ZEN, & & & 100 & $2.1-9.3$ & 0 & \\
\hline $\mathrm{T}-2$ & & & 100 & $3.9-4.9$ & 0 & \\
\hline DON, & & & 100 & 46.9-91.1 & 0 & \\
\hline CIT & & & 100 & $41.0-43.3$ & 100 & \\
\hline $\mathrm{FB}_{1}$ & \multirow{2}{*}{ Mint } & \multirow{2}{*}{2} & 50 & n.d. -0.160 & 0 & \multirow{2}{*}{ [43] } \\
\hline $\mathrm{FB}_{2}$ & & & 0 & n.d. & - & \\
\hline $\mathrm{AF}$ & Mint & 5 & 80 & $4.2-26.7$ & 50 & [49] \\
\hline $\mathrm{AF}$ & \multirow{6}{*}{ Mint } & \multirow{6}{*}{31} & 29 & $0.3-2.19$ & 11 & \multirow{6}{*}{ [61] } \\
\hline OTA & & & 45 & $0.38-12.32$ & 0 & \\
\hline HT-2 & & & 0 & - & - & \\
\hline T-2 & & & 3 & 3.81 & 0 & \\
\hline FB & & & 61 & $<$ LOQ-102.32 & 0 & \\
\hline ZEN & & & 84 & $0.11-44.74$ & 0 & \\
\hline
\end{tabular}

* Critical-under the UE regulations limits of mycotoxins; AF-Aflatoxin, OTA-Ochratoxin A, FB-Fumonisin, ZEN-Zearalenone, DON-Deoxynivalenol, CIT-Citrinin.

\subsection{Panax Ginseng (Ginseng)}

Panax ginseng C.A.Mey belongs to the Araliaceae family and is found throughout East Asia and Russia [62]. It grows wild in remote forests of Manchuria and North Korea but has become over-harvested in other parts of Asia. It is cultivated in Korea, China, and Japan for export and is widely used as a medicinal herb [63]. Although ginseng has been used by Asian cultures for thousands of years for conditions such as fatigue, mental stress, blood sugar regulation, improving libido, and supporting longevity, modern clinical studies have focused on the use of $P$. ginseng in blood sugar regulation, fatigue, and immunomodulation in human health and disease [64]. The plants grow in fertile, permeable humus soils with a slightly acidic $\mathrm{pH}$. Because they do not tolerate direct sunlight, plants must be artificially shaded. Thus, ginseng cultivation is very demanding and, in addition, the growing conditions increase the risk of contamination with molds that produce mycotoxins. Therefore, the plant has been studied for mycotoxicological contamination. The results showed that sampled ginseng roots had significant levels of AFs which exceeded acceptable standards $[38,65]$ (Table 5). 
Table 5. Analysis of the literature available on mycotoxin contamination in ginseng.

\begin{tabular}{|c|c|c|c|c|c|c|}
\hline Mycotoxins & $\begin{array}{c}\text { Sample } \\
\text { Type }\end{array}$ & $\begin{array}{l}\text { Number of } \\
\text { Samples }\end{array}$ & $\begin{array}{l}\text { Percentage } \\
\text { of Positive } \\
\text { Results (\%) }\end{array}$ & $\begin{array}{c}\text { Range of } \\
\text { Positive Results } \\
(\mu \mathrm{g} / \mathrm{kg})\end{array}$ & $\begin{array}{c}\text { Percentage of } \\
\text { “Critical"* Positive } \\
\text { Samples (\%) }\end{array}$ & Reference \\
\hline $\mathrm{AF}$ & Ginseng root & 12 & 17 & $15.1-15.2$ & 100 & [66] \\
\hline $\begin{array}{l}\text { AF } \\
\text { OTA }\end{array}$ & Ginseng & 10 & $\begin{array}{l}30 \\
40\end{array}$ & $\begin{array}{c}<0.1 \\
0.4-1.8\end{array}$ & $\begin{array}{l}0 \\
0\end{array}$ & [67] \\
\hline $\mathrm{AF}$ & Ginseng & 76 & 0 & - & - & [64] \\
\hline $\begin{array}{c}\text { AF } \\
\text { OTA }\end{array}$ & Ginseng & 2 & $\begin{array}{c}0 \\
100\end{array}$ & $\begin{array}{l}\text { n.d. } \\
3.2\end{array}$ & $\overline{0}$ & [68] \\
\hline $\begin{array}{l}\text { OTA } \\
\text { FB }\end{array}$ & Ginseng & 13 & $\begin{array}{l}0 \\
0\end{array}$ & $\begin{array}{l}- \\
-\end{array}$ & - & [69] \\
\hline $\begin{array}{c}\text { AF } \\
\text { OTA } \\
\text { HT-2 } \\
\text { T-2 } \\
\text { ZEN } \\
\text { CIT } \\
\text { FB }\end{array}$ & Ginseng & 10 & $\begin{array}{c}0 \\
0 \\
0 \\
0 \\
0 \\
0 \\
10\end{array}$ & $\begin{array}{c}0 \\
0 \\
0 \\
0 \\
0 \\
0 \\
<10\end{array}$ & $\begin{array}{l}- \\
- \\
- \\
- \\
- \\
- \\
0\end{array}$ & [65] \\
\hline $\begin{array}{l}\text { AFB1 } \\
\text { AFB2 } \\
\text { OTA }\end{array}$ & Ginseng root & 7 & 29 & $\begin{array}{c}48.8-143 \\
18.6-355 \\
-\end{array}$ & $\begin{array}{c}100 \\
100 \\
-\end{array}$ & [38] \\
\hline $\begin{array}{l}\text { AFB1 } \\
\text { AFB2 } \\
\text { AFG1 } \\
\text { AFG2 } \\
\text { OTA }\end{array}$ & $\begin{array}{l}\text { Notoginseng } \\
\text { radix et } \\
\text { rhizoma }\end{array}$ & 3 & $\begin{array}{c}100 \\
0 \\
0 \\
0 \\
0\end{array}$ & $\begin{array}{c}1.29-2.1 \\
- \\
- \\
- \\
-\end{array}$ & $\begin{array}{l}0 \\
- \\
- \\
- \\
-\end{array}$ & [70] \\
\hline
\end{tabular}

* Critical-under the UE regulations limits of mycotoxins; AF-Aflatoxin, OTA-Ochratoxin A, FB-Fumonisin, ZEN-Zearalenone, CIT-Citrinin.

\subsection{Silybum Marianum L. (Milk Thistle)}

Silybum marianum L. is commonly known as milk thistle, Marian thistle, Saint Mary's thistle, Mediterranean milk thistle, variegated thistle and Scotch thistle. This herb is an annual or biennial plant of the Asteraceae family and displays red to purple flowers and shiny pale green leaves with white veins. Originally, a native of Southern Europe through to Asia, it is now found throughout the world. Medicinally, the fruit is harvested to produce the antioxidant silymarin, since the levels of this compound make up to $2 \%$ to $3 \%$ of the fruit by weight. Silymarin is used both prophylactically (e.g., it is administered to people working with chemical vapors and ionizing radiation), as well as to promote healing in cirrhosis, hepatic steatosis, cholangitis, cholelithiasis, jaundice, and during cancer treatment. [71]. Like other herbs, this medicinal herb has been examined for mycotoxin contamination. Reports of research carried out in various centers have shown some cases of significant levels of contamination by mycotoxins, in particular AF, DON, and T-2 and HT-2, exceeding the allowed maximum limits. The results were primarily found in dietary supplements and products aimed at pregnant women. Therefore, reports that showed the presence of mycotoxins should be confirmed in order to reduce the health risks for consumers (Table 6). 
Table 6. Analysis of the literature available on mycotoxin contamination in milk thistle.

\begin{tabular}{|c|c|c|c|c|c|c|}
\hline Mycotoxins & $\begin{array}{c}\text { Sample } \\
\text { Type }\end{array}$ & $\begin{array}{c}\text { Number of } \\
\text { Samples }\end{array}$ & $\begin{array}{l}\text { Percentage } \\
\text { of Positive } \\
\text { Results (\%) }\end{array}$ & $\begin{array}{c}\text { Range of } \\
\text { Positive Results } \\
(\mu \mathrm{g} / \mathrm{kg})\end{array}$ & $\begin{array}{c}\text { Percentage of } \\
\text { “Critical"* Positive } \\
\text { Samples (\%) }\end{array}$ & Reference \\
\hline OTA, & \multirow{7}{*}{ Milk thistle } & \multirow{7}{*}{2} & 0 & $<\mathrm{LOD}$ & - & \multirow{7}{*}{ [21] } \\
\hline FBs, & & & 50 & $<$ LOD-236.7 & 100 & \\
\hline $\mathrm{AF}$ & & & 100 & $10.9-11.5$ & 100 & \\
\hline ZEN, & & & 100 & $1.6-3.5$ & 0 & \\
\hline $\mathrm{T}-2$ & & & 100 & $17.5-35.6$ & 50 & \\
\hline DON, & & & 0 & $<$ LOD & - & \\
\hline CIT & & & 0 & $<\mathrm{LOD}$ & - & \\
\hline $\mathrm{AF}$ & Milk thistle & 83 & 16 & $0.04-2.0$ & 0 & [72] \\
\hline T-2 & \multirow{3}{*}{ Milk thistle } & 2 & 100 & $363.0-453.9$ & 100 & \multirow{3}{*}{ [73] } \\
\hline HT-2 & & 2 & 100 & $826.9-943.7$ & 100 & \\
\hline ZEN & & 1 & 100 & $<\mathrm{LOD}$ & 0 & \\
\hline $\mathrm{DON}$ & Milk thistle & 32 & 3 & 2890 & 100 & [74] \\
\hline
\end{tabular}

* Critical-under the UE regulations limits of mycotoxins; AF-Aflatoxin, OTA-Ochratoxin A, FB-Fumonisin, ZEN-Zearalenone, DON-Deoxynivalenol, CIT-Citrinin.

\subsection{Zingiber Officinale (Ginger)}

Ginger (Zingiber officinale Roscoe) is a perennial root plant cultivated in tropical and subtropical climates. Due to the presence of bioactive components, the rhizomes are used primarily as a spice, but also for medicinal purposes. The increase in demand for ginger in the USA and Europe as a botanical dietary supplement is for treatment of chronic inflammation. Recent studies have demonstrated antioxidant and anti-emetic effects [75]. Products are delivered to Europe mainly from Nigeria and China, where, due to climatic conditions, they are exposed to contamination with secondary mold metabolites, usually at every stage of production, from harvesting to distribution itself [76]. As ginger is especially exposed to aflatoxins and ochratoxin $\mathrm{A}$, the European Commission has set maximum levels of $5 \mathrm{mg} / \mathrm{kg}$ for $\mathrm{AFB}_{1}, 10 \mathrm{mg} / \mathrm{kg}$ for all $\mathrm{AFs}$ (sum of $\mathrm{AFB}_{1}, \mathrm{AFB}_{2}, \mathrm{AFG}_{1}$, and $\mathrm{AFG}_{2}$ ) and $15 \mathrm{mg} / \mathrm{kg}$ for OTA $[33,77]$. As with other herbs, ginger has been studied for mycotoxin status. The results showed that in the tested samples there were samples which were contaminated with mycotoxins, but their levels did not exceed the acceptable norm, with the exception of two trials where the concentration of AFs exceeded acceptable standards [49] (Table 7).

Table 7. Analysis of the literature available on mycotoxin contamination in ginger.

\begin{tabular}{|c|c|c|c|c|c|c|}
\hline Mycotoxins & $\begin{array}{c}\text { Sample } \\
\text { Type }\end{array}$ & $\begin{array}{l}\text { Number of } \\
\text { Samples }\end{array}$ & $\begin{array}{l}\text { Percentage } \\
\text { of Positive } \\
\text { Results (\%) }\end{array}$ & $\begin{array}{c}\text { Range of } \\
\text { Positive Results } \\
(\mu \mathrm{g} / \mathrm{kg})\end{array}$ & $\begin{array}{c}\text { Percentage of } \\
\text { “Critical"* Positive } \\
\text { Samples (\%) }\end{array}$ & Reference \\
\hline $\mathrm{AF}$ & \multirow{3}{*}{ Ginger } & \multirow{3}{*}{26} & \multirow{3}{*}{50} & $0.12-0.85$ & 0 & \multirow{3}{*}{ [78] } \\
\hline OTA & & & & $0.01-0.09$ & 0 & \\
\hline $\mathrm{CIT}$ & & & & $0.00-0.02$ & 0 & \\
\hline ZEN & \multirow{2}{*}{ Ginger } & \multirow{2}{*}{27} & 7 & $13.44-14.51$ & 0 & \multirow{2}{*}{ [79] } \\
\hline $\mathrm{DON}$ & & & 15 & $4.85-10.35$ & 0 & \\
\hline $\mathrm{AF}$ & Ginger & 4 & 75 & $3.8-23.1$ & 67 & [49] \\
\hline $\mathrm{AFB}_{1}$ & \multirow{2}{*}{ Ginger } & \multirow{2}{*}{30} & \multirow{2}{*}{17} & $0.13-1.38$ & 0 & \multirow{2}{*}{ [80] } \\
\hline OTA & & & & $0.31-5.17$ & 0 & \\
\hline \multirow{4}{*}{$\begin{array}{l}\text { AF } \\
\text { OTA }\end{array}$} & \multirow{2}{*}{ Ginger rainy } & \multirow{2}{*}{31} & 81 & $0.11-9.52$ & 0 & \multirow{4}{*}{ [76] } \\
\hline & & & 77 & $0.20-9.90$ & 0 & \\
\hline & \multirow{2}{*}{ Ginger dry } & \multirow{2}{*}{89} & 46 & $0.20-3.57$ & 0 & \\
\hline & & & 37 & $0.17-12.02$ & 0 & \\
\hline
\end{tabular}

* Critical-under the UE regulations limits of mycotoxins; AF-Aflatoxin, OTA-Ochratoxin A, ZEN-Zearalenone, DON-Deoxynivalenol, CIT-Citrinin. 


\section{Conclusions}

The occurrence of mycotoxins in herbal products is still quite limited. Considering the rapidly increasing market, it is recommended that more effort should be put into the control of mycotoxins and other contaminants in plant products $[81,82]$. The quality and safety of herbal products are closely related to compliance with the principles of good agricultural practice at every stage of production. Plants classified as medical material should be carefully stored and checked for the presence of mycotoxins in order to protect the consumers who use these products to improve their health. The dose of herbal intake depends on the health of the consumer, and thus the level of mycotoxin contamination varies, and therefore the level of mycotoxins should be considered individually for each type of medicinal plant [83]. One of the challenges of international trade is the lack of common guidelines and a monitoring body to enforce the regulation of mycotoxins in herbal plants and for their products, especially for dietary supplements [84]. For many of these foods, the average consumption is low, therefore, the quantitative daily intake of mycotoxins via herbs, is possibly very low in many cases. However, the consumers' trust in such products requires the absence of avoidable levels of toxins. The complex composition of herbal products affects their quality. Poor-quality raw materials can affect the final product. [85] The agricultural production of herbs under suboptimal circumstances may be an important contributing factor to toxin levels. Although aspects of risk-benefit assessments are applicable here, mycotoxins are a consequence of fungal growth, and therefore also an indicator of hygienic deficits during production and storage. In recent years, extensive research has been conducted with regard to biological, chemical, and physical strategies for the degradation and decontamination of mycotoxins [86]. An example of mycotoxin removal is cold atmospheric pressure plasma (CAPP), which is appropriate for sensitive biological stuffs [87]. Therefore, the option for solving the problem of mycotoxins is also implementation of the Good Agricultural and Collection Practices (GACP) and the Good Manufacturing Practices (GMP) [85]. Their presence in herbal products should be used as a stimulus to improve food quality and safety, by conducting further studies on the presence of mycotoxins in such products.

Author Contributions: Conceptualization, I.A. and M.T.; Data curation, I.A.; Writing—original draft preparation, I.A., M.T.; Writing—review and editing, I.A. and M.T.; Supervision, M.T. All authors have read and agreed to the published version of the manuscript.

Funding: This study was supported by the Polish Minister of Science and Higher Education, under the program "Regional Initiative of Excellence" from 2019 to 2022 (grant no. 008/RID/2018/19).

Conflicts of Interest: The authors declare no conflict of interest.

\section{References}

1. Ong, C.K.; Bodeker, G. WHO Global Atlas of Traditional, Complementary, and Alternative Medicine. Kobe, Japan: World Health Organization, Centre for Health Development. 2005. Available online: https: //apps.who.int/iris/bitstream/handle/10665/43108/9241562862_map.pdf?sequence=1\&isAllowed=y (accessed on 15 January 2020).

2. World Health Organization. WHO Guidelines for Assessing Quality of Herbal Medicines with Reference to Contaminants and Residues. 2007. Available online: https://apps.who.int/medicinedocs/documents/s14878e/ s14878e.pdf (accessed on 15 January 2020).

3. World Health Organization. World Health Organization Resolution-Promotion and Development of Training and Research in Traditional Medicine. 1977. Available online: https://apps.who.int/iris/bitstream/handle/ 10665/93212/WHA30.49_eng.pdf?sequence=1\&isAllowed=y (accessed on 10 January 2020).

4. Bent, S. Herbal medicine in the United States: A review of efficacy, safety and regulation. J. Gen. Intern. Med. 2008, 23, 854-859. [CrossRef] [PubMed]

5. Market Research Futures. Global Herbal Medicine Market Research Report-Forecast to 2023. 2018. Available online: https://www.reuters.com/brandfeatures/venture-capital/article?id=32992 (accessed on 10 December 2010). 
6. Neergheen-Bhujun, V.S. Underestimating the toxicological challenges associated with the use of herbal medicinal products in developing countries. Biomed Res. Int. 2013, 2013, 804086. [CrossRef] [PubMed]

7. WHO (World Health Organization). 2008. Available online: http://www.who.int/mediacentre/factsheets/ Fs134/en (accessed on 13 March 2020).

8. Selwet, M. Negatywne aspekty występowania wybranych mikotoksyn w paszach. Wiadomości Zootech. 2010, 48, 9-13.

9. Zain, M.E. Impact of mycotoxins on humans and animals. J. Saudi Chem. Soc. 2011, 15, 129-144. [CrossRef]

10. Binder, E.M.; Tan, L.M.; Chin, L.J.; Handl, J.; Richard, J. World-wide occurrence of mycotoxins in commodities, feeds and feeds ingredients. Anim. Feed Sci. Technol. 2007, 137, 265-282. [CrossRef]

11. Gajęcka, M.; Jakimiuk, E.; Zielonka, Ł.; Obremski, K.; Gajęcki, M. The biotransformation of chosen mycotoxins. Pol. J. Vet. Sci. 2009, 12, 293-303.

12. Pitt, J.I. What are mycotoxins? Aust. Mycotoxin Newslett. 1996, 7, 1.

13. International Agency for Research on Cancer. Monographs on the evaluation of the carcinogenic risk of chemicals to humans: Some naturally occurring substances. In Food Items and Constituents, Heterocyclic Aromatic Amines and Mycotoxins; IARC: Lyon, France, 1993; Volume 56, pp. 245-521.

14. Petzinger, E.; Ziegler, K. Ochratoxin A from a toxicological perspective. J. Vet. Pharmacol. Ther. 2000, 23, 91-98. [CrossRef]

15. European Food Safety Authority (EFSA). Deoxynivalenol in food and feed: Occurrence and exposure. Efsa J. 2013, 11, 337.

16. European Food Safety Authority (EFSA). Scientific Opinion on risks for animal and public health related to the presence of nivalenol in food and feed. Efsa J. 2013, 13, 3262.

17. European Union (EU). Directive 2004/24/EC of the European parliament and of the council of 31 March 2004 amending, as regards traditional herbal medicinal products, Directive 2001/83/EC on the Community code relating to medicinal products for human use. Off. J. Eur. Union 2004, 136, 85-90. Available online: https://ec.europa.eu/health/documents/eudralex/vol-1_de (accessed on 10 December 2019).

18. International Agency for Research on Cancer. Monographs on the evaluation of carcinogenic risks to humans. In Some Traditional Herbal Medicines, Some Mycotoxins, Naphthalene and Styrene; IARC: Lyon, France, 2002; Volume 82.

19. Joint Expert Committee on Food Additives and Contaminants (JECFA). Evaluation of certain contaminants in foods. In Proceedings of the 82 Report of the Joint FAO/WHO Expert Committee on Food Additives, Rome, Italy, 8-17 November 2016; Available online: http://www.fao.org/food/food-safetyquality/scientificadvice/ jecfa/jecfaadditives/detail/en/c/484/ (accessed on 10 December 2019).

20. Miller, J.D. Fungi and mycotoxins in grain: Implications for stored product research. J. Stored Prod. 1995, 31, 1-16. [CrossRef]

21. Santos, L.; Marin, S.; Sanchis, V.; Ramos, A.J. Screening of mycotoxin multicontamination in medicinal and aromatic herbs sampled in Spain. J. Sci. Food Agric. 2009, 89, 1802-1807. [CrossRef]

22. Zhang, L.; Dou, X.W.; Zhang, C.; Logrieco, A.F.; Yang, M.H. A Review of Current Methods for Analysis of Mycotoxins in Herbal Medicines. Toxins 2018, 10, 65. [CrossRef] [PubMed]

23. Sharma, S. Current status of herbal products: Regulatory Overview. J. Pharm. Bioallied Sci. 2015, 7, $293-296$. [CrossRef] [PubMed]

24. Dar, A.S.; Ganai, F.A.; Yousuf, A.R.; Balkhi, M.H.; Bhat, T.M.; Sharma, P. Pharmacological and toxicological evaluation of Urtica Dioca. Pharm. Biol. 2013, 51, 170-180. [CrossRef] [PubMed]

25. Leciejewicz-Ziemecka, E. Ocena zanieczyszczeń w surowcach farmaceutycznych jako element wymagań farmakopealnych. Biul. Inst. Lek. 2000, 44, 239-409.

26. Convention on International Trade in Endangered Species. Convention on International Trade in Endangered Species of Wild Fauna and Flora. 1983. Available online: https://www.cites.org/eng/disc/text.php (accessed on 20 January 2020).

27. World Health Organization. World Health Organization Traditional Medicine Strategy: 2002-2005. 2001. Available online: http://www.wpro.who.int/health_technology/book_who_traditional_medicine_strategy_ 2002_2005.pdf (accessed on 25 November 2019).

28. World Health Organization. WHO Traditional Medicine Strategy: 2014-2023. 2013. Available online: http://www.searo.who.int/entity/health_situation_trends/who_trm_strategy_2014-2023.pdf?ua=1 (accessed on 25 November 2019). 
29. Schilter, B.; Andersson, C.; Anton, R.; Constable, A.; Kleiner, J.; O’Brien, J.; Renwick, A.G.; Korver, O.; Smit, F.; Walker, R. Guidance for the safety assessment of botanicals and botanical preparations for use in the food and food supplements. Food Chem. Toxicol. 2003, 41, 1625-1649. [CrossRef]

30. European Food Safety Authority (EFSA). Guidance on safety assessment of botanicals and botanical preparations intended for use as ingredients in food supplements, on request of EFSA. Efsa J. 2009, 7, 1249.

31. European Pharmacopeia. Determination of aflatoxin B1 in herbal drugs. Eur. Pharmacop. 2006, 7, 4801-4802.

32. Official Journal of the European Union. Directive 2004/24/EC. 31 March 2004. Available online: http: //www.eur-lex.europa.eu/LexUriServ/LexUriServ (accessed on 25 November 2019).

33. European Commission (EC). European Commission Regulation (EC) No. 1881/2006 of 19 December 2006 setting maximum levels for certain contaminants in foodstuffs, 2006. Off. J. Eur. Union 2006, 364, 5-24.

34. European Commission (EC). European Commission Regulation (EC) No. 1126/2007 of 28 September 2007 amending Regulation (EC) No 1881/2006 setting maximum levels for certain contaminants in foodstuffs as regards Fusarium toxins in maize and maize products. Off. J. Eur. Union 2007, 255, 14-17.

35. European Commission (EC). Imposing Special Conditions Governing the Import of Certain Feed and Food from Certain Third Countries Due to Contamination Risk by Aflatoxins and Repealing. Regulation (EC) No 1152/2009. 2014. Available online: http://food.gov.uk/business-industry/imports/banned_restricted/ highrisknonpoao (accessed on 25 November 2019).

36. European Pharmacopoeia. Council of Europe European Directorate for the Quality of Medicines (EDQM), 7th ed.; European Pharmacopoeia: Strasbourg, France, 2011.

37. Anukul, N.; Vangnai, K.; Mahakarnchanakul, W. Significance of regulation limits in mycotoxin contamination in Asia and risk management programs at the national level. J. Food Drug Anal. 2013, 21, 227-241. [CrossRef]

38. Su, C.; Hu, Y.; Gao, D.; Luo, Y.; Chen, A.J.; Jiao, X.; Hao, W. Occurrence of Toxigenic Fungi and Mycotoxins on Root Herbs from Chinese Markets. J. Food Prot. 2018, 81, 754-761. [CrossRef]

39. Karkanis, A.; Martins, N.; Petropoulos, S.A.; Ferreira, I.C.F.R. Phytochemical composition, health effects, and crop management of liquorice (Glycyrrhiza glabra L.): A medicinal plant. Food Rev. Int. 2018, 34, 182-203. [CrossRef]

40. Bresch, H.; Urbanek, M.; Nusser, M. Ochratoxin A in food containing liquorice. Nahrung 2000, 44, $276-278$. [CrossRef]

41. Tan, Y.; Kuang, Y.; Zhao, R.; Chen, B.; Wu, J. Determination of T-2 and HT-2 toxins in traditional Chinese medicine marketed in China by LC-ELSD after sample clean-up by two solid-phase extractions. Chromatographia 2011, 73, 407-410. [CrossRef]

42. Huang, X.; Wang, S.; Mao, D.; Miao, S.; Hu, Q.; Hi, S. Optimized QuEChERS method combined with UHPLC-MS/MS for the simultaneous determination of 15 mycotoxins in liquorice. J. AOAC Int. 2018, 101, 633-642. [CrossRef]

43. Omurtag, G.Z.; Yazicioglu, D. Determination of fumonisin B1 and B2 in herbal tea and medicinal plants in Turkey by high performance liquid chromatography. J. Food Prot. 2004, 67, 1782-1786. [CrossRef]

44. Roy, A.K.; Sinha, K.K.; Chourasia, H.K. Aflatoxin Contamination of Some Common Drug Plants. Appl. Environ. Microbiol. 1988, 54, 842-843. [CrossRef]

45. Roy, A.K.; Chourasia, H.K. Mycoflora, mycotoxins producibility and mycotoxins in traditional herbal drugs from India. J. Gen. Appl. Microbiol. 1990, 36, 295-302. [CrossRef]

46. Ariño, A.; Herrera, M.; Estopañan, G.; Juan, T. High levels of ochratoxin A in licorice and derived products. Int. J. Food Microbiol. 2007, 114, 366-369. [CrossRef] [PubMed]

47. Pietri, A.; Rastelli, S.; Bertuzzi, T. Ochratoxin A and Aflatoxins in Liquorice Products. Toxins 2010, 2, 758-770. [CrossRef] [PubMed]

48. Han, Z.; Zheng, Y.; Luan, L.; Ren, Y.; Wua, Y. Analysis of ochratoxin A and ochratoxin B in traditional Chinese medicines by ultra-high-performance liquid chromatography-tandem mass spectrometry using [13C20,ochratoxin A as an internal standard. J. Chromatogr. 2010, 1217, 4365-4374. [CrossRef]

49. Tosun, H.; Arslan, R. Determination of aflatoxin B1 levels in organic spices and herbs. Sci. World J. 2013, 2013, 874093. [CrossRef]

50. Wang, L.; Wang, Z.; Gao, W.; Chen, J.; Yang, M.; Kuang, Y.; Huang, L.; Chen, S. Simultaneous determination of aflatoxin B1 and ochratoxin A in licorice roots and fritillary bulbs by solid-phase extraction coupled with high-performance liquid chromatography-tandem mass spectrometry. Food Chem. 2013, 138, 1048-1054. [CrossRef] 
51. Ahmad, B.; Ashiq, S.; Hussain, A.; Bashir, S.; Hussain, M. Evaluation of mycotoxins, mycobiota, and toxigenic fungi in selected medicinal plants of Khyber Pakhtunkhwa. Fungal Biol. 2014, 118, 776-784. [CrossRef]

52. Singh, O.; Khanam, Z.; Misra, N.; Srivastava, M.K. Chamomile (Matricaria chamomilla L.): An overview. Pharmacogn. Rev. 2011, 5, 82-95. [CrossRef]

53. Martins, M.L.; Martins, H.M.; Bernardo, F. Fumonisins B1 and B2 in black tea and medicinal plants. J. Food Prot. 2001, 64, 1268-1270. [CrossRef]

54. Conway, G.A.; Slocumb, J.C. Plants used as abortifacients and emmenagogues by Spanish new Mexicans. J. Ethnopharmacol. 1979, 1, 241-261. [CrossRef]

55. Nazem, V.; Sabzalian, M.R.; Saeidi, G.; Rahimmalek, M. Essential oil yield and composition and secondary metabolites in self- and open-pollinated populations of mint (Mentha spp.). Ind. Crop. Prod. 2019, 130, 332-340. [CrossRef]

56. Halt, M. Moulds and mycotoxins in herb tea and medicinal plants. Eur. J. Epidemiol. 1998, 14, $269-274$. [CrossRef] [PubMed]

57. Rizzo, I.; Vedoya, G.; Maurutto, S.; Haidukowski, M.; Varsavsky, E. Assessment of toxigenic fungi on Argentine an medicinal herbs. Microbiol. Res. 2004, 159, 113-120. [CrossRef] [PubMed]

58. Š̌krinjar, M.; Mandić, A.I.; Mišan, A.Č.; Sakač, M.B.; Šarič, L.Č.; Zec, M.M. Effect of mint (Mentha piperita L.) And caraway (Carum carvi L.) on the growth of some toxigenic Aspergillus species and aflatoxin B1 production. Proc. Nat. Scimatica Srp. Novi Sad 2009, 116, 131-139. [CrossRef]

59. Liu, L.; Jin, H.; Sun, L.; Ma, S.; Lin, R. Determination of Aflatoxins in Medicinal Herbs by High-performance Liquid Chromatography-Tandem Mass Spectrometry. Phytochem. Anal. 2012, 23, 469-476. [CrossRef]

60. Shim, W.B.; Kim, K.; Ofori, J.A.; Chung, Y.C.; Chung, D.H. Occurrence of aflatoxins in herbal medicine distributed in South Korea. J. Food Prot. 2012, 75, 1991-1999. [CrossRef]

61. Luo, J.; Zhou, W.; Dou, X.; Qin, J.; Zhao, M.; Yang, M. Occurrence of multi-Class mycotoxins in Menthae haplocalycis analyzed by ultra-Fast liquid chromatography coupled with tandem mass spectrometry. J. Sep. Sci. 2018, 41, 3974-3984. [CrossRef]

62. Seely, D.; Dugoua, J.J.; Perri, D. Safety and efficacy of Panax ginseng during pregnancy and lactation. J. Clin. Pharm. 2008, 15, 87-94.

63. Weiss, R. Herbal Medicine; Beaconsfield Publishers LTD: Gothenburg, Sweden, 1988; pp. 176-177.

64. Lee, D.; Lyu, J.; Lee, K.G. Analysis of aflatoxins in herbal medicine and health functional foods. Food Control 2015, 48, 33-36. [CrossRef]

65. Bi, B.; Bao, J.; Xi, G.; Xu, Y.; Zhang, L. Determination of multiple mycotoxin residues in Panax ginseng using simultaneous UPLC-ESI-MS/MS. J. Food Saf. 2018, 38, 12458. [CrossRef]

66. D'Ovidio, K.; Trucksess, M.; Weaver, C.; Horn, E.; McIntosh, M.; Bean, G. Aflatoxins in ginseng roots. Food Addit. Contam. 2006, 23, 174-180. [CrossRef] [PubMed]

67. Trucksess, M.; Weaver, C.; Oles, C.J.; Rump, L.V.; White, K.D.; Betz, J.M.; Rader, J.I. Use of multitoxin immunoaffinity columns for determination of aflatoxins and ochratoxin $\mathrm{A}$ in ginseng and ginger. J. AOAC Int. 2007, 90, 1042-1049. [CrossRef] [PubMed]

68. Filipiak-Szok, A.; Kurzawa, M.; Szłyk, E.; Twarużek, M.; Błajet-Kosicka, A.; Grajewski, J. Determination of mycotoxins alkaloids, phytochemicals antioxidants and cytotoxicity in Asiatic ginseng (Ashwagandha, Dong Quai, Panax ginseng). Chem. Pap. 2017, 71, 1073-1082. [CrossRef] [PubMed]

69. Li, Z.; Ji, G.E. Ginseng fermented by mycotoxin non-producing Aspergillus niger: Ginsenoside analysis and anti-proliferative effects. Food Sci. Biotechnol. 2017, 26, 987-991. [CrossRef]

70. Chen, L.; Guo, W.; Zheng, Y.; Zhou, J.; Liu, T.; Chen, W.; Liang, D.; Zhao, M.; Zhu, Y.; Wu, Q.; et al. Occurrence and characterization of fungi and mycotoxins in contaminated medicinal herbs. Toxins 2020, 12, 30. [CrossRef]

71. Wianowska, D.; Gil, M. Silymarin Extraction from Silybum marianum L. Gaertner. In Water Extraction of Bioactive Compounds from Plants to Drug Development, 1st ed.; Elsevier: Cambridge, MA, USA, 2017; pp. 385-397.

72. Tournas, V.H.; Sapp, C.; Trucksess, M.W. Occurrence of aflatoxins in milk thistle herbal supplements. Food Addit. Contam. 2012, 29, 994-999. [CrossRef] 
73. Arroyo-Manzanares, N.; Garcia-Campaña, A.M.; Gámiz-Gracia, L. Multiclass mycotoxin analysis in Silybum marianum by ultra-high-performance liquid chromatography-tandem mass spectrometry using a procedure based on QuEChERS and dispersive liquid-liquid microextraction. J. Chromatogr. A 2013, 1282, 11-19. [CrossRef]

74. Veprikova, Z.; Zachariasova, M.; Dzuman, Z.; Zachariasova, A.; Fenclova, M.; Slavikova, P.; Vaclavikova, M.; Mastovska, K.; Hengst, D.; Hajslova, J. Mycotoxins in Plant-Based Dietary Supplements: Hidden Health Risk for Consumers. J. Agric. Food Chem. 2015, 63, 6633-6643. [CrossRef]

75. Badreldin, H.A.; Blunden, G.; Musbah, O.T. Some phytochemical, pharmacological and toxicological properties of ginger (Zingiber officinale Roscoe): A review of recent research. Food Chem. Toxicol. 2008, 46, 409-420.

76. Lippolis, V.; Irurhe, O.; Porricelli, A.C.R.; Cortese, M.; Schena, R.; Imafidon, T.; Oluwadun, A.; Pascale, M. Natural co-Occurrence of aflatoxins and ochratoxin A in ginger (Zingiber officinale) from Nigeria. Food Control 2017, 73, 1061-1067. [CrossRef]

77. European Commission (EC). Commission Regulation (EC) No 594/2012 of 5 July 2012 amending Regulation (EC) 1881/2006 as regards the maximum levels of the contaminants ochratoxin A, non dioxin-like PCBs and melamine in foodstuffs. Off. J. Eur. Union 2012, 176, 43-45.

78. Chourasia, H.K. Mycobiota and mycotoxins in herbal drugs of Indian pharmaceutical industries. Mycol. Res. 1995, 99, 697-703. [CrossRef]

79. Koul, A.; Sumbali, G. Detection of zearalenone, zearalenol and deoxynivalenol from medicinally important dried rhizomes and root tubers. Afr. J. Biotechnol. 2008, 7, 4136-4139.

80. Wen, J.; Kong, W.; Hu, Y.; Wang, J.; Yang, M. Multi-Mycotoxins analysis in ginger and related products by UHPLC-FLR detection and LC-MS/MS confirmation. Food Control 2014, 43, 82-87. [CrossRef]

81. European Food Safety Authority (EFSA). Advice on the EFSA guidance document for the safety assessment of botanicals and botanical preparations intended for use as food supplements, based on real case studies. ESCO working group on botanicals and botanical preparations. Efsa J. 2009, 7, 280.

82. European Food Safety Authority (EFSA). Panel on Contaminants in the Food Chain (CONTAM) 2016, Appropriateness to set a group health-based guidance value for zearalenone and its modified forms. Efsa J. 2016, 14, 4425.

83. Ashiq, S.; Hussain, M.; Ahmad, B. Natural occurrence of mycotoxins in medicinal plants: A review. Fungal Genet. Biol. 2014, 66, 1-10. [CrossRef]

84. Tripathy, V.; Basak, B.B.; Varghese, T.S.; Saha, A. Residues and contaminants in medicinal herbs-A review. Phytochem. Lett. 2015, 14, 67-78. [CrossRef]

85. Zhang, J.; Wider, B.; Shang, H.; Li, X.; Ernst, E. Quality of herbal medicines: Challenges and solutions. Complement. Ther. Med. 2012, 20, 100-106. [CrossRef]

86. Kabak, B.; Dobson, A.D.W.; Var, I. Strategies to Prevent Mycotoxin Contamination of Food and Animal Feed: A Review. Crit. Rev. Food Sci. Nutr. 2006, 46, 593-619. [CrossRef]

87. Abbas, M. Co-Occurrence of Mycotoxins and Its Detoxification Strategies. Mycotoxins-Impact and Management Strategies. 2018, Volume 5, pp. 91-107. Available online: https://www.intechopen.com/books/mycotoxinsimpact-and-management-strategies/co-occurrence-of-mycotoxins-and-its-detoxification-strategies (accessed on 20 January 2020).

(C) 2020 by the authors. Licensee MDPI, Basel, Switzerland. This article is an open access article distributed under the terms and conditions of the Creative Commons Attribution (CC BY) license (http://creativecommons.org/licenses/by/4.0/). 